\title{
Implementasi Supervisi Pendidikan Untuk Meningkatkan Proses Pembelajaran di MAN 1 Kota Palembang
}

\author{
Meli Astriani, Cecilia Indriani, Dilla Eka Septiani, Herman Seri
}

\section{(C) 2021 JEMS (Jurnal Edukasi Matematika dan Sains)}

This is an open access article under the CC-BY-SA license

(https://creativecommons.org/licenses/by-sa/4.0/) ISSN 2337-9049 (print), ISSN 2502-4671 (online)

\section{Abstrak:}

Penelitian ini bertujuan untuk mengetahui kendala guru dalam proses pembelajaran daring. Pembelajaran di masa pandemi saat ini menuntut guru untuk melaksanakan pembelajaran yang berkualitas. Metode penelitian menggunakan metode deskriptif kuantitatif dan kualitatif dengan sampel guru biologi kelas X, XI, dan XII. Teknik pengumpulan data terdiri atas wawancara dan observasi yang dilakukan melalui kunjungan kelas virtual dan keterlaksanaan RPP daring. Hasil penelitian didapatkan bahwa RPP yang dibuat oleh guru telah memenuhi standar yang telah ditetapkan oleh pemerintah dan ada beberapa guru yang tidak mencantumkan atau tidak melampirkan soal serta pembahasannya. Sehingga mengurangi penilaian dalam pengukuran indikator. Hasil Analisis data menunjukkan kemampuan mengajar guru telah memenuhi predikat baik.

Kata Kunci : Supervisi, guru biologi, MAN 1 Palembang, pembelajaran daring

\begin{abstract}
:
This study aims to determine the teacher's obstacles in the online learning process. Learning during the current pandemic requires teachers to carry out quality learning. The research method uses quantitative and qualitative descriptive methods with samples of biology teachers in grades X, XI, and XII. The data collection technique consisted of interviews and observations conducted through virtual class visits and the implementation of online lesson plans. The results of the study found that the lesson plans made by teachers had met the standards set by the government and there were some teachers who did not include or did not attach questions and discussions. Thus reducing the assessment in the measurement of indicators. The results of the data analysis showed that the teacher's teaching ability had met the predicate good..
\end{abstract}

Keywords : supervision, biology teacher, MAN 1 Palembang, online learning

\section{Pendahuluan}

Pendidikan memiliki peran yang sangat penting bagi suatu negara. Pendidikan yang berkualitas akan tercermin dari peningkatan kualitas sumber daya manusia serta perekonomiannya. Menurut Norhasanah (2019) melalui pendidikan setiap orang berhak untuk meningkatkan kualitas hidupnya, mempelajari ilmu pengetahuan dan teknologi, serta memiliki kesempatan untuk mengenyam pendidikan terutama pendidikan formal di sekolah. Proses Pendidikan di sekolah perlu melibatkan peran guru dalam memberikan ilmu pengetahuan secara kompleks kepada peserta didik. Guru bertugas untuk mencetak serta menghasilkan generasi berkualitas, serta memiliki semangat kerja tinggi dan bersungguh-sungguh dalam menjalankan profesi, dengan demikian kinerja guru dapat menentukan kemajuan pendidikan. 
yang diperoleh seorang dalam pekerjaannya dengan kemampuan yang bersungguhsungguh untuk mencapai tujuan. Jadi dapat disimpulkan bahwa kinerja guru merupakan kemampuan serta motivasi yang tinggi yang harus dimiliki dalam melaksanakan tusnya pada proses pembelajaran untuk mencapai keberhasilan pendidikan. Guru profesional adalah guru yang memiliki kesiapan dalam merencanakan dan melaksanakan proses belajar mengajar. Administrasi yang harus disiapkan oleh guru dalam perencanaan proses pembelajaran meliputi silabus, RPP yang memuat identitas alokasi waktu, pelajaran, kompetensi inti, tujuan, materi pelajaran, metode, kegiatan pembelajaran hingga penilaian (Riyadi, 2016) sedangkan pelaksanaan pembelajaran adalah kegiatan belajar mengajar yang dilakukan guru di dalam kelas dimulai dari kegiatan awal hingga penutupan.

Peran guru dalam pembelajaran menjadi salah satu tolok ukur keberhasilan dalam pembelajaran. Berbagai masalah tentunya dihadapi guru pada saat mengajar ditambah lagi berbagai tuntutan profesionalitas guru untuk mampu menghasilkan peserta didik yang mandiri dan kritis. Untuk mendukung tercapainya tujuan Pendidikan, guru memerlukan rekan dalam memberi masukan, pendapat maupun bantuan. Rekan senior atau pihak yang kompeten dibutuhkan untuk mengulas cara/teknik guru dalam mengajar di kelas. Peningkatan pembelajaran perlu guru perlu diperbaiki melalui pengembangan professional guru yang dapat dilakukan dengan Teknik supervisi (Sabandi, 2013).

Supervisi merupakan salah satu alternatif bagi guru untuk mengetahui kelemahan guru dalam mengajar (Ilham, 2017). Menurut Riyadi (2016) supervisi pendidikan merupakan bantuan yang diberikan kepada guru untuk meningkatkan proses belajar mengajar baik dari motivasi guru dalam mengajar serta keterampilan guru dalam menyajikan pembelajaran. Jadi, Supervisi berfungsi dalam memperbaiki proses pembelajaran guru di kelas (Rachmawati, 2016). Hal ini sejalan dengan pendapat Gusnilawati \& Hadiyanto (2021) menyatakan kegiatan supervisi bisa membantu guru dalam memecahkan masalah saat proses pembelajaran. Aktivitas ini biasanya direncanakan untuk menilai guru secara efektif. Seorang supervisor dapat memberikan dorongan motivasi kepada guru untuk mencari solusi untuk menyelesaikan masalah yang ditemui pada saat proses pembelajaran. Dalam pelaksaan supervisi perlu untuk memperhatikan 3 unsur yang dianggap penting, yaitu a) Unsur orang yang memberi pengarahan baik dari pihak atasan atau yang memahami, b) unsur dari pihak guru yang langsung berhubungan dengan proses pembelajaran serta siswa yang terlibat, c) unsur pada proses pembelajaran sebagai hal akan diperbaiki (Sihombing, 2014).

Supervisor memiliki tugas untuk memberi pemecahan dan solusi mengenai masalah yang ditemui pada pembelajaran di kelas. Apalagi proses pembelajaran pada saat pandemi saat ini, akan banyak permasalahan yang akan ditemui oleh guru, baik dari segi teknik pembelajaran sampai pelaksaan melalui daring. Supervisi harus dilaksanakan secara objektif dan realistis agar hasil yang diperoleh dapat membantu guru me-review pola pembelajaran yang telah dilakukan, sehingga supervisi menjadi usaha untuk meningkatkan akselerasi belajar di kelas sehingga dapat meningkatkan serta menggali potensi yang ada di diri peserta didik.

Saat ini bukan hanya di Indonesia bahkan seluruh dunia mengalami dampak pandemi virus Covid-19 yang menyebabkan banyak orang terinfeksi virus ini, untuk memutus rantai penyebaran virus. Pemerintah mengupayakan pembelajaran dilaksanakan secara daring (dalam jaringan) dengan menggunakan google form, whatsapp, zoom Meting, dan lainnya. Adanya perubahan proses pembelajaran saat ini serta dengan keterbatasan yang ada maka supervisi juga dilaksanakan secara virtual dengan mengamati guru saat mengajar pada ruang zoom meeting (Warmansyah, 2020).

Supervisi individual dengan melaksanakan kunjungan ke dalam kelas oleh supervisor memiliki tujuan untuk meninjau proses pembelajaran yang dilaksanakan guru di dalam 
kelas. Kunjungan kelas memudahkan supervisor memantau serta melihat cara guru mengajar sehingga diperolah data yang riil sehingga supervisor dapat mengevaluasi cara mengajar guru. Faktor pendukung dari supervisor dapat membuat kepala sekolah dan guru termotivasi melaksanakan pemebelajaran dengan baik untuk belajar membuat RPP dengan baik dan melatih guru dalam menggunakan metode mengajar (Slameto, 2016).

Menurut Glickman dalam Darsono (2016) mengkategorikan guru dalam empat tipe yaitu 1) Professional teacher merupakan guru yang memiliki komitmen dan berpikir abstrak tinggi, 2) Teacher criticism adalah guru yang memiliki komitmen rendah tetapi kemampuan berpikirnya tinggi, 3) Unfocused worker adalah guru yang memiliki komitmen tinggi tetapi kemampuan berpikirnya rendah, dan 4) Teacher drop out adalah guru yang memiliki komitmen dan kemampuan berpikir abstraknya rendah.

Dari penjelasan di atas, maka penelitian ini perlu dilakukan untuk melihat dan meninjau kemampuan guru dan melaksanakan proses belajar mengajar serta merencanakan pembelajaran serta melihat sejauh mana manfaat supervisi individual dengan kunjungan kelas ini dapat berjalan dengan baik untuk meningkatkan kinerja guru di MAN 1 Palembang.

\section{Metode}

Penelitian dilaksanakan di Madrasah Aliyah Negeri (MAN) 1 Kota Palembang. Penelitian ini merupakan penelitian deskriptif kualitatif untuk melihat kemampuan guru dalam merencanakan dan melaksanakan pembelajaran. Sasaran supervisi adalah supervisi akademik untuk melihat kemampuan guru mengajar dan masalah yang dihadapi serta supervisi administrasi meliputi silabus, RPP, dan indikator RPP. Objek supervisi adalah guru biologi di kelas X, XI dan XII.

Pengambilan data dengan cara observasi langsung melalui tinjauan ke kelas virtual dimana guru sedang mengajar secara daring melalui zoom meeting. Teknik supervisi yang digunakan adalah teknik individual dimana supervisor langsung melihat secara langsung guru yang mengajar serta waktu yang sudah ditetapkan sebelumnya, selanjutnya supervisor mengevaluasi kinerja guru serta melaksanakan tindak lanjut. Teknik ini bertujuan untuk meninjau kinerja guru dalam mengajar serta mengetahui permasalahan yang dihadapi. Model supervisi yang di gunakan adalah supervisi ilmiah karena pelaksanaanya dilakukan secara terencana, menggunakan prosedur dan teknik tertentu, serta menggunakan instrumen observasi untuk menilai kinerja guru dan menilai secara objektif.

Instrumen penelitian menggunakan lembar observasi untuk menilai Rencana Pelaksanaan Pembelajaran (RPP) dengan indikator meliputi tujuan pembelajaran, pemilihan materi ajar, pemilihan sumber belajar, model pembelajaran. Sedangkan, instrumen kompetensi guru menggunakan lembar penilaian untuk meninjau proses pembelajaran di kelas virtual menggunakan indikator penggunaan model pembelajaran, penggunaan media, dan penguasaan kompetensi.

Analisis data deskriptif kuantitatif diperoleh dari pengisian angket pada lembar observasi. Skor penilaian kompetensi mengajar dan kelengkapan RPP berdasarkan skala likert dengan modifikasi sesuai kebutuhan yang disajikan pada table 1 dan 2 .

Tabel 1. Penilaian kompetensi mengajar

\begin{tabular}{llllll}
\hline No. & Indikator & \multicolumn{5}{c}{ Skor } \\
\cline { 3 - 6 } & & \multicolumn{1}{c}{ Apersepsi } & & & \\
\hline 1 & & & & & \\
2 & Pemakaian metode & & & & \\
3 & Penggunaan media & & & & \\
\hline
\end{tabular}




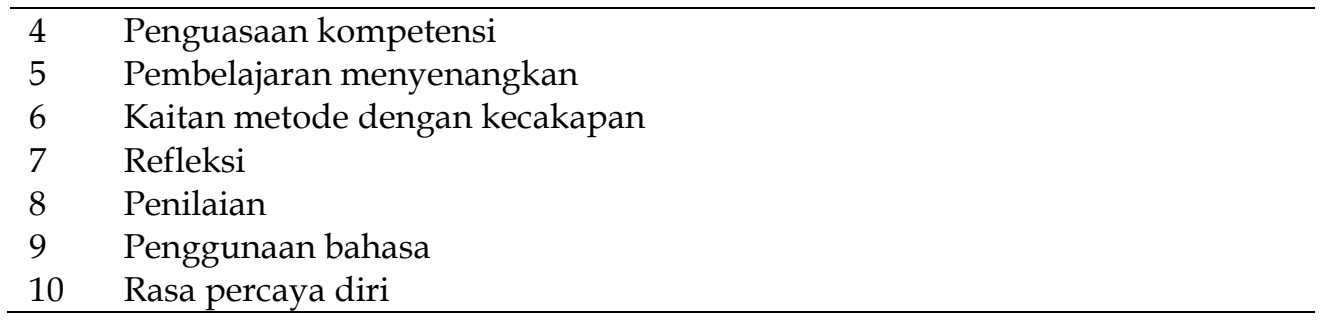

Hasil penilaian dilanjutkan dengan analisis persentase dan dekskripsi kualitatif. Data pengisian angket yang diperoleh akan dilakukan perhitungan persentase dari tiap butir pertanyaan pada lembar penilaian menggunakan rumus berikut.

$$
\sum \text { Nilai yang diperoleh }=\frac{-}{40} \times 100
$$

Hasil persentase penilaian akan disesuaikan dengan kriteria pengambilan keputusan nilai: $\leq 60=$ Kurang

$60-69=$ Cukup

$70-79=$ Baik

$80-89=$ Sangat baik

$90-100=$ Istimewa

Tabel 2. Penilaian Komponen RPP

\begin{tabular}{|c|c|c|c|c|c|}
\hline \multirow[t]{2}{*}{ No } & \multirow[t]{2}{*}{ Komponen RPP } & \multicolumn{4}{|c|}{ Skor } \\
\hline & & 1 & 2 & 3 & 4 \\
\hline 1 & $\begin{array}{l}\text { Identitas } \\
\text { Terdapat: satuan pendidikan, kelas, semester, } \\
\text { program/program keahlian, mapel, jumlah tatp muka }\end{array}$ & & & & \\
\hline 2 & $\begin{array}{l}\text { Rumusan Indikator } \\
\text { Sesuaian dengan SKL, KI (Kompetensi Inti) dan KD } \\
\text { (Kompetensi Dasar) } \\
\text { Penggunaan kata kerja telah sesuai dengan kompetensi yang } \\
\text { dicapai } \\
\text { Suaian dengan aspek pengetahuan, sikap dan keterampilan }\end{array}$ & & & & \\
\hline 3 & $\begin{array}{l}\text { Tujuan Pembelajaran } \\
\text { Sesuai dengan proses pembelajaran dan hasil belajar } \\
\text { Sesuai dengan kompetensi dasar yang dicapai }\end{array}$ & & & & \\
\hline 4 & $\begin{array}{l}\text { Pemilihan Materi Ajar } \\
\text { Sesuai dengan tujuan pembelajaran yang ada } \\
\text { Sesuai dengan karakteristik peserta didik di kelas } \\
\text { Sesuai dengan materi yang diajarkan }\end{array}$ & & & & \\
\hline 5 & $\begin{array}{l}\text { Pemilihan Sumber Belajar } \\
\text { Sesuai dengan KI dan KD } \\
\text { Sesuai dengan pendekatan yang digunakan dan materi yang } \\
\text { akan diajarkan } \\
\text { Sesuai dengan karakteristik peserta didik }\end{array}$ & & & & \\
\hline 6 & $\begin{array}{l}\text { Sesuai dengan tujuan pembelajaran } \\
\text { Sesuai dengan materi pembelajaran dan pendekatan scientifik } \\
\text { Sesuai dengan karakteristik peserta dididk }\end{array}$ & & & & \\
\hline 7 & $\begin{array}{l}\text { Model Pembelajaran } \\
\text { Sesuai dengan tujuan pembelajaran } \\
\text { Sesuai dengan pendekatan scientifik }\end{array}$ & & & & \\
\hline
\end{tabular}


$8 \quad$ Skenario Pembelajaran

Menampilkan kegaiatan pendahuluan, inti dan penutup

dengan jelas

Sesuai kegiatan dengan pendekatan scientifik

Sesuai penyajian dengan sistematika materi

Sesuai alokasi waktu dengan cakupan materi

9 Penilaian

Sesuai dengan teknik dan bentuk penilaian autentik

Sesuai dengan indicator pencapaian kompetensi

Sesuai kunci jawaban dengan soal

Sesuai pedoman penskoran dengan soal

Persentase Nilai Akhir $=\frac{\text { skor Perolehan }}{\text { Skor Maksimal }} \times 100 \%$

Hasil persentase penilaian komponen RPP disesuaikan dengan kriteria pengambilan keputusan atau predikat ketercapaian sebagai berikut.

Ketercapaian: $\quad 86 \%-100 \%$ = Baik Sekali

$70 \%-85 \%=$ Baik

$55 \%-69 \%=$ Cukup

Di bawah $55 \%=$ Kurang

\section{Hasil dan Pembahasan}

Berdasarkan hasil pengamatan mengenai instrumen kelengkapan komponen administrasi pembelajaran didapatkan bahwa semua guru telah melengkapi administrasi berupa program tahunan, program semester, silabus, RPP, kalender pendidikan, jadwal tatap muka, agenda harian, dan daftar nilai. Berdasarkan penilaian terhadap instrumen dari indikator RPP diperoleh hasil rekapitulasinya sebagai berikut.

Tabel 3. Penilaian terhadap Komponen RPP

\begin{tabular}{cccc}
\hline No & Nama guru & Nilai & Predikat \\
\hline 1 & A & 70 & Baik \\
2 & B & 76 & Baik \\
3 & C & 77 & Baik \\
4 & D & 75 & Baik \\
5 & E & 79 & Baik \\
\hline
\end{tabular}

Berdasarkan tabel 3 disimpulkan bahwa RPP yang dibuat oleh guru telah memenuhi standar yang telah ditetapkan oleh pemerintah terutama pada keadaan daring. Pemerintah memberikan kebebasan kepada guru untuk menginovasi sendiri RPP satu lembar dengan mengedepankan efektivitas, efisiensi dan berorientasi kepada peserta didik (Permendiknas, 2019). Penilaian RPP masih ditemukan beberapa kekurangan pada aspek penilaian yang digunakan guru meliputi rubrik penilaian autentik dan lembar tes yang tidak mencantumkan pembahasan dan melampirkan soal. Hal ini dapat mengurangi penilaian dalam pengukuran indikator.

Aspek penilaian pada RPP menjadi penting hal ini sejalan dengan yang dikemukakan Perrotta \& Whitelock (2017) bahwa penilaian dapat membantu peserta didik dan guru untuk fokus pada tujuan pembelajaran mereka, mendorong penilaian dan pembelajaran untuk dilihat sebagai satu kesatuan yang terintegrasi, dan melibatkan umpan balik dari peserta didik ke guru, ini menjadi penting karena guru membutuhkan informasi ini dari peserta didik untuk memodifikasi pengajaran mereka secara efektif. Beberapa kendala atau 
kesulitan yang dihadapi oleh guru saat memberikan penilaian autentik adalah keterbatasan waktu, jumlah peserta didik yang banyak, dan kesulitan mengarahkan peserta didik sesuai dengan tujuan pembelajaran (Zuhera et al., 2017). Untuk mengatasi hal tersebut menurut (Perrotta \& Whitelock, 2017) ada beberapa solusi dalam menerapkan penilaian pembelajaran salah satunya adalah sekolah perlu mendorong guru untuk bekerja sama dalam meninjau dan mengembangkan kebijakan, serta praktik penilaian sehingga penilaian dipandang sebagai metode yang positif dalam mendorong peserta didik untuk belajar dan memahami tanpa menjadi beban kerja guru serta memastikan bahwa umpan balik bentuk tertulis dan lisan telah akurat, mudah dipahami dan terfokus pada pembelajaran, menjadikan evaluasi sebagai strategi baru yang diterapkan, dan guru juga dapat menggunakan pertanyaan untuk memeriksa dan memperdalam pemahaman peserta didik di dalam dan di seluruh pelajaran.

Penilaian guru terhadap pembelajaran faktanya menjadi tantangan tersendiri bagi guru. Keterbatasan kemampuan guru dalam mengembangkan rubrik penilaian sangat terbatas. Beberapa guru mengeluhkan kesulitan dan belum terbiasa untuk melaksanakan penilaian dengan lengkap seperti menilai keterampilan siswa. Sejauh ini penilaian yang sering dilakukan guru terhadap hasil belajar aspek kognitif. Sedangkan evaluasi formatif masih membingungkan guru untuk instrumennya. Penilaian formatif dilakukan guru untuk menilai materi pembelajaran, interaksi langsung, dan melihat perkembangan siswa dari waktu ke waktu. Beberapa instrumen formatif yang telah dilakukan dengan LKS jika pembelajaran menggunakan media konvensional (Nurjannah, 2017). Hasil penilaian menjadi tolak ukur guru dalam melakukan evaluasi jangka panjang, serta guru harus dapat menjelaskan kepada orang tua untuk membantu peserta didik dalam mengembangkan aspek sikap, kognitif dan psikomotoriknya. Namun, kenyataannya penilaian menjadi beban kerja guru padahal penilaian menjadi aspek terpenting dan harus ditanamkan dalam praktik sehari-hari di kelas. Elemen penting dalam penilaian yang dilakukan guru dapat mendorong untuk memperbaiki proses pembelajaran. Hasil analisis kemampuan guru dalam mengajar disajikan pada tabel 4 .

Tabel 4. Hasil Analisis data kemampuan mengajar guru

\begin{tabular}{cccc}
\hline No & Nama guru & Nilai & Predikat \\
\hline 1 & A & 73 & Baik \\
2 & B & 70 & Baik \\
3 & C & 83 & Baik \\
4 & D & 70 & Baik \\
5 & E & 72 & Baik \\
\hline
\end{tabular}

Berdasarkan Tabel 4, dapat disimpulkan bahwa kinerja guru dalam mengajar telah memenuhi predikat baik. Untuk kedepannya lebih ditingkatkan agar dapat menciptakan inovasi baru dalam pembelajaran. Kinerja guru yang telah memenuhi predikat baik dapat berpengaruh positif dengan hasil belajar peserta didik. Menurut (Helmi, 2015) kinerja guru dapat membantu peserta didik yang mengalami kesulitan belajar, serta dapat mengevaluasi proses hasil belajar peserta didik baik segi kognitif, psikomotorik dan afektif.

Hal ini sesuai dengan hasil observasi yang telah dilakukan dimana hasil belajar peserta didik untuk bidang kognitif sudah melewati KKM. Sedangkan menurut (Asmawati, 2003) hasil belajar peserta didik semakin meningkat dengan semakin besarnya usaha guru 
untuk mengembangkan kemampuan peserta didik. Namun, keberhasilan peserta didik juga tidak lepas dari peran penting orang tua peserta didik dalam pembelajaran.

\section{Simpulan}

Evaluasi proses pembelajaran di MAN 1 kota Palembang telah berjalan dengan baik untuk kegiatan guru dalam mengajar serta kelengkapan administrasi berupa RPP, silabus, jadwal mengajar. Namun, masih terdapat kekurangan pada komponen penilaian yang dilakukan guru. Kedepannya proses umpan balik (guru ke peserta didik) diharapkan dapat mengoptimalkan pembelajaran di kelas. Kinerja guru juga sudah memenuhi predikat baik dapat menciptakan inovasi baru dalam pembelajaran dan berpengaruh positif terhadap hasil belajar peserta didik.

\section{Daftar Rujukan}

Asmawati. (2003). Pengaruh Kinerja Guru terhadap Hasil Belajar. Pedagogy, 2(1), 44-53.

Darsono. (2016). Implementasi Pendekatan Direktif, Non Direktif dan Kolaboratif dalam Supervisi Pendidikan islam Studi Kasus di MAN Trenggalek. Jurnal Ta'alum. 4 (2), 335-358

Faizah, U. (2019). Evaluasi Kinerja Pendidik Dan Tenaga Kependidikan Dan Proses Pembelajaran Pendidikan Islam Di Indonesia. Al-Fikri: Jurnal Studi Dan Penelitian Pendidikan Islam, 2(2), 44-54.

Gusnilawati, H., \& Hadiyanto, H. (2021). Pelaksanaan Supervisi Klinis Untuk Meningkatkan Proses Pembelajaran IPA Di Sekolah Dasar. JEMS: Jurnal Edukasi Matematika dan Sains, 9(1), 113-118.

Helmi, A. (2015). Kinerja Guru Dalam Meningkatkan Prestasi Siswa Pada Smp Negeri 2 Babahrot Aceh Barat Daya. Jurnal Administrasi Pendidikan: Program Pascasarjana Unsyiah, 3(1), 1-12.

Ilham, M. W. (2017). Supervisi Pendidikan dalam Perspektif Epistemologi Islam. PEDAGOGIK: Jurnal Pendidikan, 4(1), 29-46.

Nurjannah, N. (2017). Efektivitas bentuk penilaian formatif disesuaikan dengan media pembelajaran. PARAMETER: Jurnal Pendidikan Universitas Negeri Jakarta. 29(1), 75-90.

Perrotta, C., \& Whitelock, D. (2017). Assessment for learning. Technology Enhanced Learning: Research Themes, 127-135.

Rachmawati, T. (2016). Supervisi Pendidikan Sebagai Upaya Meningkatkan Kinerja Guru. Jurnal Coopetition. 7 (1), 43-52.

Sihombing. (2014). Meningkatkan Kinerja Guru Biologi SMA Negeri Dalam Pembelajaran Melalui Supervisi Klinis. Jurnal Manajemen Pendidikan Indonesia. 6 (2), 77-96.

Sunadi, A. (2013). Supervisi Pendidikan Untuk Pengembangan Profesionalitas Guru Berkelanjutan. Jurnal Pedagogi. 13 (2), Hal 1-9. 
Slameto. (2016). Supervisi Pendidikan Oleh Pengawas Sekolah. Jurnal Manajemen Pendidikan. $3(2), 192-206$.

Warmansyah. (2020). Supervisi Akademik Kepala Sekolah Taman Kanak-kanak Dimasa Pandemi Covid 19. Jurnal Studi Manajemen Pendidikan. 4 (2), 176-185.

Zuhera, Y., Habibah, S., \& Mislinawati. (2017). Kendala Guru dalam Memberikan Penilaian Terhadap Sikap Siswa dalam Proses Pembelajaran Berdasarkan Kurikulum 2013 di SD Negeri 14 Banda Aceh. Ilmiah Pendidikan Guru Sekolah Dasar. 2(1), 73-87. 